\title{
Eucalyptus erythrocoris: a source of nectar and pollen for honey bees in Israel
}

\author{
A Lupo *, D Eisikowitch \\ Department of Botany, The George $S$ Wise of Life Sciences, \\ Tel Aviv University, Tel Aviv 69978, Israel
}

(Received 4 December 1988; accepted 16 June 1989)

\begin{abstract}
Summary - Eucalyptus erythrocoris F Muell blooms between July and September in Israel, when sources of nectar and pollen are scarce. A survey of $E$ erythrocoris was conducted and the characteristics and environmental requirements of the trees in different biotopes were recorded. The flower phenology was studied and amounts of nectar secreted and nectar sugar concentrations determined. During the 4 days of its bloom, a single flower secretes $4 \mathrm{ml}$ of nectar, which contain nearly half a gram of sugar. There was a high correlation between the foraging behaviour of the honey bees and the stages of nectar secretion and pollen release. Thus, it was concluded that, in addition to its nectar contribution, this tree is an important source of pollen. For this reason, together with its beautiful flowers and its environmental requirements, $E$ erythrocoris is recommended as an ornamental tree in Israel.
\end{abstract}

\section{Eucalyptus erythrocoris / nectar secretion / nectar plant / pollen plant / Israel}

\section{INTRODUCTION}

The end of the summer (August to September) is the most difficult time of the year for honey bees in Israel. This period is characterized by oppressive heat, drought and a shortage of nectar and pollen. Brood production in the colonies therefore, decreases and bee populations are reduced. Other negative conditions at this time of the year, such as insecticide applications to cotton crops, attacks of Varroa mite and wax moth and (in September) the destruction of worker bees at the hive entrances by the wasp, Vespa orientallis also contribute to decreasing bee populations.

Supplemental feeding with sugar syrup at this time helps the bees, but it does not supply the pollen necessary for reproduc- tion. In addition to the economic cost, supplemental feeding during this dry period often stimulates robbing between colonies. Areas which are planted with blooming plants during this season are rare, except for cotton fields and these are sprayed intensively with insecticides.

A partial solution of this problem might be achieved by establishing plants that bloom during August and September. However, such planting is not feasible if it does not have some additional economic or ecological value. $E$ erythrocoris, in addition to having its main blooming time in August, and being very attractive to honey bees, has beautifully coloured buds and flowers and is classified as 1 of the eucalypts than can be used as ornamentals (Anonymous, 1979). Like all other species of this genus, it originates in Australia where it grows on the south-west coast

\footnotetext{
* Correspondence and reprints.
} 
at a latitude of $29-32^{\circ} \mathrm{S}$. The ecological conditions in its natural habitat are (Anonymous, 1979): total winter rainfall of 470 $\mathrm{mm}$; dry season 6-7 months during the warmer part of the year - which can be severe; mean maximum of the warmest month more than $30^{\circ} \mathrm{C}$; mean minimum of the coldest month below $10^{\circ} \mathrm{C}$; frost is rare. The latitude, in the opposite hemisphere is similar to that in Israel, and these ecological conditions are therefore, also quite similar to those found in the coastral plain of Israel and other areas on the Mediterranean.

Because the tree grows to a height of 6-8 metres, it can be used as an ornamental in these areas, which is how it is widely used in Australia and in California, USA.

We describe here the flower phenology and give results of quantitative studies of nectar secretion and sugar concentration. Behaviour of honey bees on the flowers was observed and recorded. Ecological requirements in Israel were deduced from a survey of the existing trees already in the country.

\section{MATERIALS AND METHODS}

The blooming season of $E$ erythrocoris in Tel Aviv was achieved by recording the beginning and the termination of blooming during 4 successive years. Exceptional cases of single blooming flowers were not included. Flowers were marked with hanging labels, on which the serial number and the date of anthesis were recorded. Flowers were covered with bags of organdy cloth to prevent visits by insects during the day of the experiment.

Nectar was collected from 16 flowers (4 of each age) with Vitrex glass capillaries calibrated to 100 microlitres each, and its concentration was measured by a hand-held refractometer (Bellingham and Stanley). The ambient temperature and relative humidity were recorded throughout the period of data collection.
In observations on bee activity, collecting nectar (fig 8) and collecting pollen (fig 9) we tried to find the formula for the best line to describe the dispersal of the points. (Nie et al, 1969). Data was collected from 5-10 flowers of each age during the whole day at intervals of 30 min. Pollen collectors were distinguished from nectar collectors by their behavior. Pollen collecting bees scratch on the anthers, while the nectar collectors penetrated under the stamens into the flowers and sucked motionless.

\section{RESULTS}

\section{Blooming period and Flower develop- ment}

The main blooming period of $E$ erithrocoris in Tel Aviv Israel, as recorded over a period of 4 years, is July-September, but mainly in August (table I).

Young green buds (fig 1a) develop on new sprouting branches during the summer, usually appearing in groups of 3 . At maturity (fig $1 \mathrm{~b}$ ) the operculum of the bud changes its colour from green to purplered. The flower opens by shedding the red operculum, exposing hundreds of folded yellow stamens (fig $1 \mathrm{c}$ ). The fruits grow up to $45 \mathrm{~mm}$ in diameter.

The blooming period of the single flower lasts 4 days (fig 2 ) and is as follows:

Table I. The main blooming period of $E$ erythrocoris in Tel Aviv.

\begin{tabular}{cl}
\hline Year & \multicolumn{1}{c}{ Period } \\
\hline 1983 & 1st August - 8th September \\
1984 & 10th July - 11th September \\
1985 & 15th July - 9th September \\
1986 & 7th July - 9th September \\
\hline
\end{tabular}




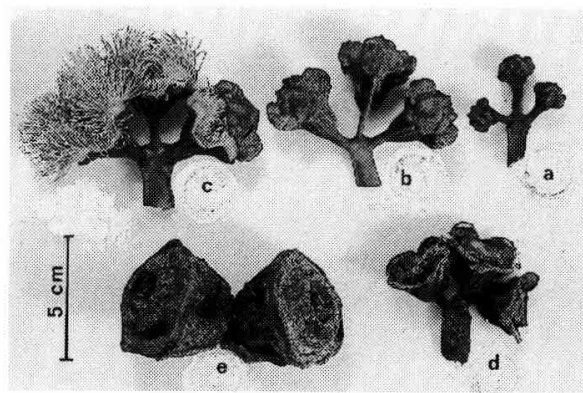

Fig 1. The different stages from bud to fruiting (a) Small green bud; (b) Grown bud with red operculum; (c) Flowers at various stages of opening; (d) The hypanthium and the lower ovary adhering to it after the flowering; (e) ripe fruit.

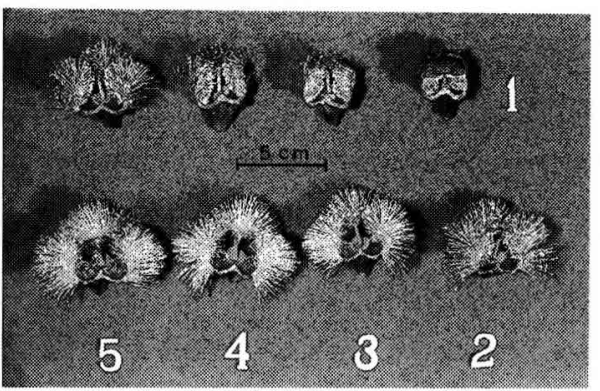

Fig 2. The stages of flower development. The numbers indicate the day from opening. In all the flowers, one "brush" of stamens was cut-out to reveal the nectaries and the pistil.

First day - sheeding of the operculum, gradual straightening of stamens to a perpendicular position. Nectar secretion and beginning of anther opening.

Second day - full straightening of stamens which form 4 yellow "brushes".

Open anthers. High nectar secretion.

Third day - Empty anthers. Nectar secretion diminishing.

Fourth day - Nectar secretion ceases.

\section{Nectar secretion}

Each flower of $E$ erythrocoris secretes nectar over a period of 4 days. Nectar volume reaches about $1 \mathrm{ml}$ per flower on the first day, rises to $1.8 \mathrm{ml}$ on the second day, drops back to about $1.2 \mathrm{ml}$ on the third day and drops drastically to about $0.2 \mathrm{ml}$ by the fourth day (fig 3).

The daily sugar yield per flower measured was about $100 \mathrm{mg}$ on the first day, rising to over $200 \mathrm{mg}$ on the second day, dropping to some $150 \mathrm{mg}$ on the third day and again dropping by the fourth day to 20 mg (fig 3). The amount of secreted sugar (fig 4) is relatively low on the first day, high on the second day and decreases by midday on the third day, until it ceases altogether by noon on the fourth day.

Nectar concentration rises gradually during the first 3 days between $5 \mathrm{~h} 00$ to $17 \mathrm{~h} 00$ and then drops (fig 5). This can be explained by the changes in the ambient relative humidity (fig 6). On the fourth day this concentration rises steeply, probably
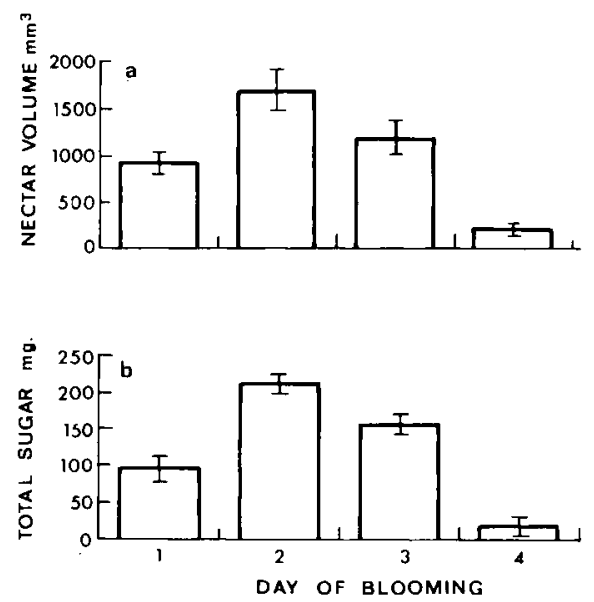

Fig 3. Daily total secretion of nectar (microlitres) and sugar (milligrams) on each of 4 days of bloom. l = standard error. 


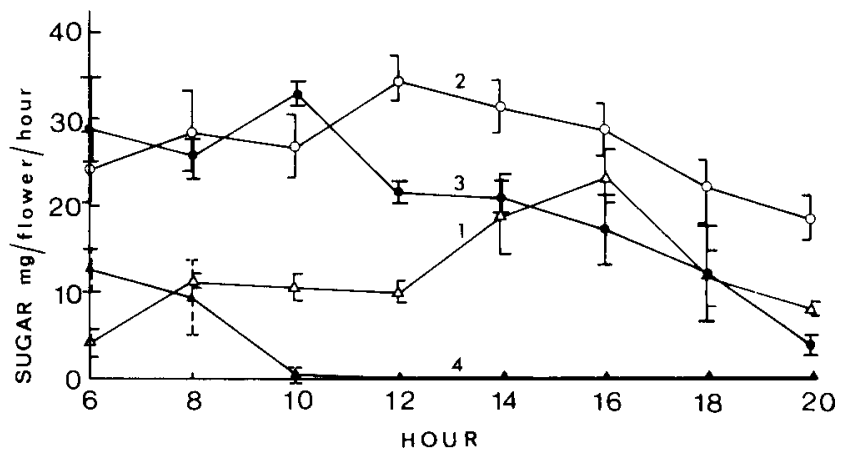

Fig 4. Hourly amounts of sugar $(\mathrm{mg})$ secreted during 4 days of bloom. I = standard errors of the different days.

due to the evaporation of the minute amounts of nectar present at that time (figs 5 and 7).

\section{The activity of honeybees on E erythro- coris flowers}

During the blooming season of $E$ erythrocoris, the sound of honey bees working among the blossoms can be heard from dawn until sunset. The bees collect nectar or pollen and sometimes 5 or more bees are seen visiting a single flower.

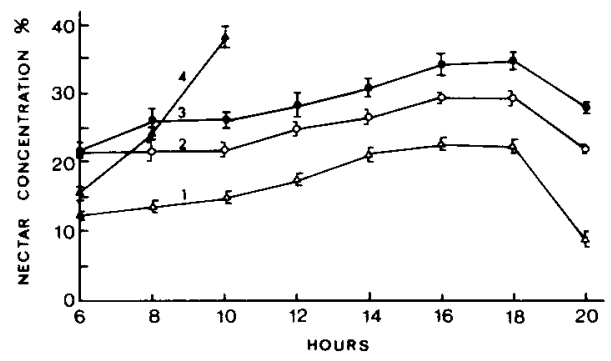

Fig 5. Hourly nectar concentrations (\%) during 4 days of bloom. Legend as in fig 4.

\section{Nectar collectors (fig 8)}

On the first day of flower opening, the number of bees per flower increased gradually until an average of 1.6 bees were seen. On the second and third day there was a very high activity among nectar collectors (1-2 bees or more per flower) during most of the daytime. In some cases, 5 nectar-collecting bees were observed on a single flower. Bee visits diminished on the fourth day to a mean of 0.8 bees per flower during the peak period. On the fifth day there were virtually no visits of nectar collectors.

\section{Pollen collectors (fig 9)}

Pollen collection began on the first day of anthesis, after the stamens became straight and the anthers opened. The mean number of pollen collectors per flower increased gradually to 2.5 bees per flower by the end of the first day. During the morning of the second day, a mean of 2 bees, on average, was observed on each flower. The number of bees visiting 


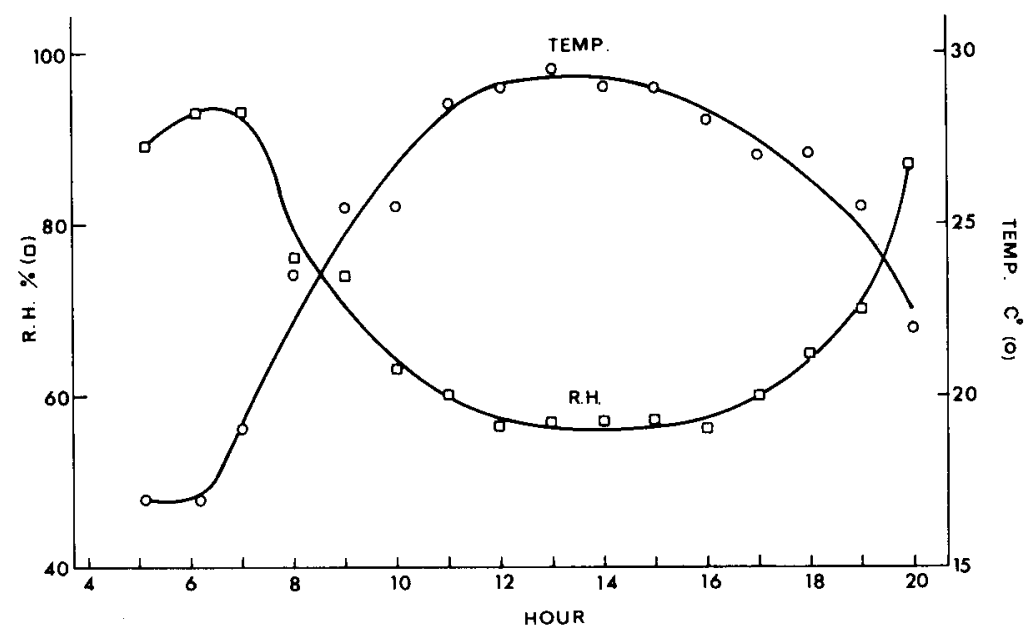

Fig 6. The ambient temperature and humidity during the day of testing.

declined by $12 \mathrm{~h} 00$ and, on the third day and thereafter, there was no pollen collection.

\section{Development of the trees in various ec- ological circumstances}

The ecological conditions in the natural habitat of $E$ erythrocosis in Australia are similar to those in the coastal plain of israel, so that it can be expected that these

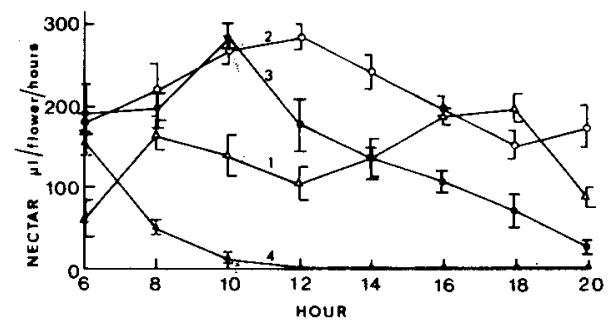

Fig 7. Hourly nectar secretion (1) during 4 days of bloom. Legend as in fig 4. trees will easily flourish in such an area. To determine its ecological requirements, all the known sites in Israel in which this tree was found, were surveyed. The main conclusions are as follows:

1. E erythrocoris grows well in the coastal plain, with about $550 \mathrm{~mm}$ of rain during the winter (October-March), (Anonymous, 1970 ), both on sandy loam and alluvium soils.

2. E erythrocoris suffers in arid areas with an annual precipitation of less than 250 $\mathrm{mm}$; the trees look unthrifty, even after 20 years.

3. The tree is able to grow on rendzina soil (found on Mount Carmel).

4. It responds well to supplementary water during the dry summer, especially on sandy soils.

5. The tree has a tendency toward a declining trunk and/or branches unrelated to wind direction. Such a situation can be rectified by pruning or cutting down, and thus encouraging regeneration (fig 10). 


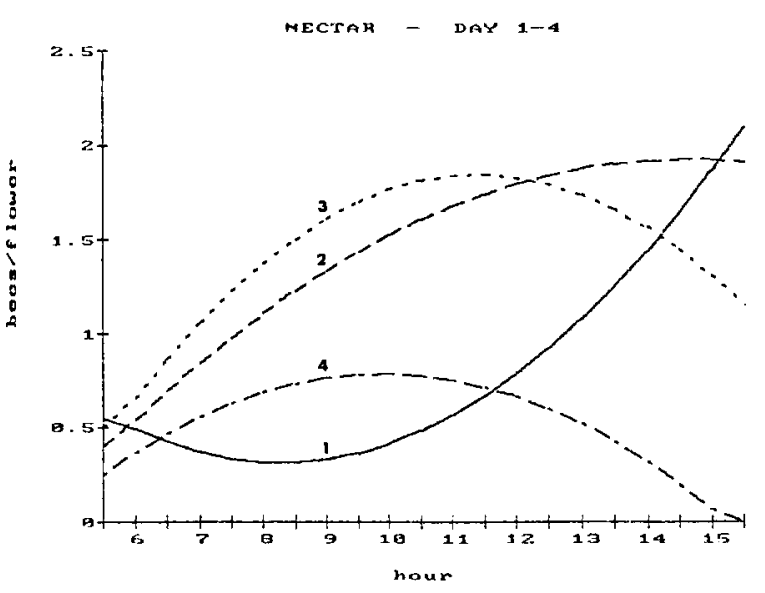

Fig 8. The activity of nectar-collecting honeybees on $E$ erythrocoris flowers of different ages (day of blooming marked by number). On first day $P<0.0001, r=0.85, y=0.034 x^{2}-0.571 x+2.683$; on second day $P<0.0001, \mathrm{r}=0.80, \mathrm{y}=-0.019 \mathrm{x}^{2}+0.544 \mathrm{x}-2.058$; on third day $P<0.0001, \mathrm{r}=0.76, \mathrm{y}=$ $-0.041 x^{2}+0.933 x-3.468$; on fourth day $P<0.0001, r=0.84, y=-0.028 x^{2}+0.551 x-1.937$

\section{DISCUSSION}

E erythrocoris has a fixed blooming time during July-September, but mainly in Au- gust. The large amount of nectar (over 4 $\mathrm{ml} /$ flower) which contains nearly half a gram of sugar, in addition to the abundance of pollen that is supplied by the flow-

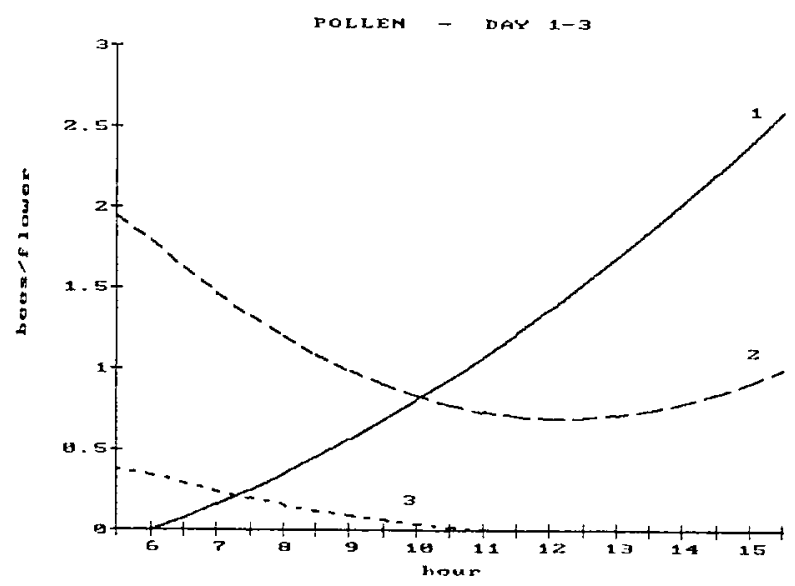

Fig 9. The activity of pollen collecting bees on $E$ erythrocoris flowers of different ages (day of blooming marked by number). On first day $P<0.0001, r=0.87, y=0.013 x^{2}-0.472$; on second day $P<$ $0.0001, r=0.65, y=0.29 x^{2}-0.702 x+4.972$; on third day $P<0.0001, r=0.77, y=0.009 x^{2}-0.217 x$ +1.330 . 


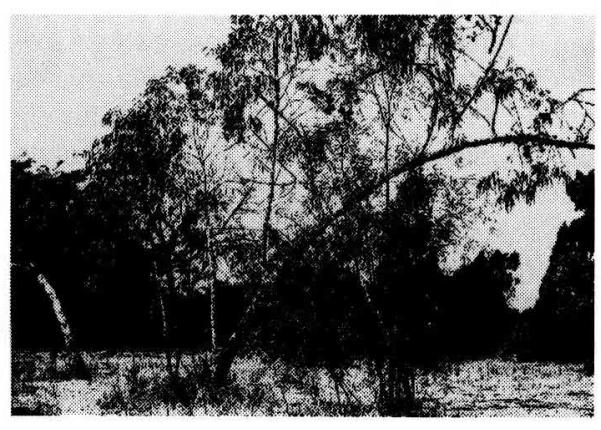

Fig 10. Regeneration of the tree after cutting down, strong decline of the trunk and appearance of crossed trunks.

ers, makes this tree very useful for honey bees. This is enhanced by the blooming period that occurs during summer (JulySeptember) when there is a dearth of blossoms.

A tree of $E$ erythrosis that grows under favourable conditions, can bear about 2000 flowers, which will yield more than 8 litres of nectar, containing 970 grams of sugar. In a sparse plantation $(6 \times 6 \mathrm{~m})$ with 28 trees per $0.1 \mathrm{Ha}\left(1000 \mathrm{~m}^{2}\right)$, we can expect a sugar yield, under good conditions, of $25 \mathrm{~kg} / 0.1 \mathrm{Ha}$ to be collected during a relatively short period of about 6-8 wks. In a more dense plantation $(4 \times 4 \mathrm{~m})$ with 62 trees per $0.1 \mathrm{Ha}$ we can expect a sugar yield of $60 \mathrm{~kg} / 0.1 \mathrm{Ha}$.

The relatively dilute nectar $(9 \%-14 \%)$ does not detract from the attractive qualities of these flowers to honey bees because in this very hot period of the year, the bees collect water for thermoregulation of the colony. Perhaps the dilute nectar is, in such circumstances, even an advantage (Eisikowitch and Masad, 1982).

From a forestry point of view, it may be that other Eucalyptus spp would be preferred, but the beautiful blooms of $E$ erythrocoris and its contribution to beekeeping, in addition to its relatively small dimensions (6-8 $\mathrm{m}$ in height) should give it priority for planting in parks and recreation areas, as well as in urban gardens.

The winter rainfall of about $550 \mathrm{~mm}$, which occurs on the coastal plain of Israel, is sufficient for the growth of this tree without irrigation, but additional water sources might improve and accelerate the growth, appearance, and productivity of the trees.

The reason for the degeneration of $E$ erythrocoris in areas with below 200-250 $\mathrm{mm}$ of annual rainfall appears to be the shortage of water and not edaphic factors. We suggest, therefore, that this species be tested under irrigated gardening conditions, even in the arid regions. In Israel, $E$ erythrocoris is unable to reproduce spontaneously and this fact ensures that it will not get out of control and become a weed.

The observations and experiments in this research show a high correlation between nectar secretion and pollen release, reflected also in the collecting activity of the bees. In areas where the wasp, Vespa orientalis, is common, this wasp also visits the flowers for nectar and startles honey bees so that they fly away. Other insects collecting nectar, such as Drosophila flies and some small beetles, are very rare and can be ignored as competitors for nectar.

Because of its important contribution to the food of honey bees, together with its beautiful flowers and considering its environmental requirements, $E$ erythrocoris is recommended as an ornamental tree in certain parts of Israel. Similar conclusions can be drawn for other countries with a Mediterranean climate.

\section{ACKNOWLEDGMENTS}

We thank Dr J Reves for assistance with the survey; $\mathrm{Mr}$ A Shub, for the photography; $\mathrm{Dr}$ 
Grauer and $\mathrm{Mr} \mathrm{R}$ Taicher, for their advice in statistical analysis and elaboration of the curves by computer; Professor D Gerling for his critical reading of the manuscript; Miss $R$ Suzin who drew the graphs; Mrs R Direktor who edited and typed the manuscript and to the Ministry of Agriculture who financed this research.

Résumé - Eucalyptus erythrocoris, source de nectar et de pollen pour les abeilles en Israël. Eucalyptus erythrocoris $F$ Muell fleurit en Israël de juillet à septembre, mais principalement en août. A cette période les sources de nectar et de pollen sont rares et la plante est donc visitée intensivement par les abeilles. Un inventaire d'E erythrocoris a été réalisé dans tous le pays et les caractéristiques, ainsi que les exigences écologiques de ces arbres, ont été relevées dans différents biotopes d'Israël.

Des fleurs marquées ont été recouvertes d'un sac en organdi et le nectar a été prélevé toutes les 2 heures à l'aide de microcapillaires. La concentration en sucre a été mesurée avec un réfractomètre de poche. Une fleur dure 4 jours et secrète 4 $\mathrm{ml}$ de nectar, qui renferment presqu'un demi gramme de sucre. La sécrétion s'étend de l'aube au crépuscule.

Le nombre de butineuses de nectar et de pollen par fleur a été enregistré toutes les $30 \mathrm{mn}$ pendant les 4 jours que dure l'anthèse. Une corrélation élevée existe entre le comportement de butinage des abeilles et les stades de secrétion nectarifère et de libération du pollen. On en conclut que cet arbre, outre son importance comme plante nectarifère, représente une source pollinique importante pour les abeilles. La faible concentration du nectar $(9-14 \%)$ ne nuit pas à l'attractivité des fleurs pour les abeilles car, à cette période très chaude de l'année, celles-ci ont besoin de beaucoup d'eau pour assurer la thermorégulation.
En raison de son importance comme plante butinée par les abeilles, de ses exigences écologiques et de la beauté de ses fleurs, $E$ erythrocoris est recommandé comme arbre ornemental dans certaines régions d'Israël.

Eucalyptus erythrocoris / sécrétion nectarifère / plante nectarifère / Source pollinique / Israël

\section{Zusammenfassung - Eucalyptus ery-} throcoris: Eine Nektar- und Pollentrachtquelle in Israel. Eucalyptus erythrocoris F. Muell. blüht in Israel von Juli bis September, aber hauptsächlich im August. In dieser Zeit gibt es nur wenig Nektar und Pollen; deshalb wird diese Pflanze von Bienen reich beflogen. Im ganzen Land erfolgte eine Bestandsaufnahme von $E$ erythrocoris, wobei die Besonderheiten und Umweltansprüche der Bäume in verschiedenen Biotopen Israels festgehalten wurden.

Markierte Blüten wurden mit OrgandyBeuteln umhüllt und alle zwei Stunden wurde mit Mikrokapillaren Nektar abgenommen. Die Konzentration wurde mit einem Taschenrefraktometer gemessen.

Die Blühdauer einer Blüte beträgt 4 Tage. Die Einzelblüte sondert $4 \mathrm{ml}$ Nektar ab, welcher fast ein halbes Gramm Zucker enthält. Die Nektarsekretion hält über den ganzen Tag an, von der Morgen- bis zur Abenddämmerung.

Die Anzahl der nektar- und pollensammelnden Bienen pro Blüte wurde während der gesamten Blühzeit von vier Tagen alle 30 Minuten festgehalten. Es wurde eine hohe Korrelation zwischen dem Sammelverhalten der Bienen und dem Stadium der Nektarsekretion und Pollenfreigabe gefunden. Es kann daraus geschlossen werden, daß dieser Baum neben seiner Bedeutung als Nektarpflanze auch ein wichtiger Pollenlieferant ist. Die geringe Konzentration 
des Nektars (9-14\%) bedeutet keine Schmälerung der Attraktivität dieser Blüten für die Bienen, da sie in dieser sehr heißen Jahreszeit viel Wasser zur Thermoregulation benötigen.

Eucalyptus erythrocoris wird wegen seiner Bedeutung als Trachtpflanze für Bienen, seinen ökologischen Ansprüchen und der Schönheit seiner Blüten in Teilen von Israel als ornamentaler Baum empiohlen.

Eucalyptus erythrocoris / Nektarsekretion / Nektarpflanze / Pollentrachtquelle / Israel

\section{REFERENCES}

Anonymous (1970) Atlas of Israel; cartography, physical geography, human and economic geography, history. Jerusalem, Survey of Israel. Ministry of Labour

Anonymous (1979) Eucalyptus for planting. Food and agriculture Organization of the United Nations, Rome, 677 pp

Eisikowitch D, Masad Y (1982) Preferences of honey bees for different ornamental nectaryielding plants during the dearth period in Israel. Bee World 63, 77-82

Nie NH, Hull HC, Jenkins JG, Steinbrenner $K$, Bent DH (1975) SPSS Mcgraw Hill NY, 675 $\mathrm{pp}$ 